\title{
ESSAY
}

\section{The End of History for Corporate Law}

\author{
Henry Hansmann* and Reinier KraAKman**
}

\section{INTRODUCTION}

Much recent scholarship has emphasized institutional differences in corporate governance, capital markets, and law among European, American, and Japanese companies. ${ }^{1}$ Despite very real differences in the corporate systems, the deeper tendency is toward convergence, as it has been since the nineteenth century. The basic law of corporate governance - indeed, most of corporate law-has achieved a high degree of uniformity across developed market jurisdictions, and continuing convergence toward a single, standard model is likely. The core legal features of the corporate form were already well established in advanced jurisdictions one hundred years ago, at the turn of the twentieth century. Although there remained considerable room for variation in governance practices and in the fine structure of corporate law throughout the twentieth century, the pressures for further convergence are now rapidly growing. Chief among these pressures is the recent dominance of a shareholder-centered ideology of corporate law among the business, government, and legal elites in key commercial jurisdictions. There is no longer any serious competitor to the view that corporate law should principally strive to increase long-term shareholder value. This emergent consensus has already profoundly affected corporate governance practices throughout the world. It is only a matter of time before its influence is felt in the reform of corporate law as well.

\section{Convergence Past: The Rise of the Corporate Form}

We must begin with the recognition that the law of business corporations had already achieved a remarkable degree of worldwide convergence at the end of the nineteenth century. By that time, large-scale business enterprise in every major commercial jurisdiction had come to be organized in the corporate form, and the core functional features of that form were essentially identical across these jurisdictions. Those features, which continue to characterize the corporate form today, are: (1) full legal personality, including well-defined authority to

\footnotetext{
* Professor, Yale Law School.

** Professor, Harvard Law School.

1. See, e.g., Bernard S. Black \& John C. Coffee, Jr., Hail Britannia?: Institutional Investor Behavior Under Limited Regulation, 92 Mich. L. Rev. 1997 (1994); Ronald J. Gilson \& Mark J. Roe, Understanding the Japanese Keiretsu: Overlaps Between Corporate Governance and Industrial Organization, 102 YALE L.J. 871 (1993); Mark J. Roe, Some Differences in Company Structure in Germany, Japan, and the United States, 102 YALE L.J. 1927 (1993).
} 
bind the firm to contracts and to bond those contracts with assets that are the property of the firm, as distinct from the firm's owners; ${ }^{2}(2)$ limited liability for owners and managers; (3) shared ownership by investors of capital; (4) delegated management under a board structure; and (5) transferable shares.

These core characteristics, both individually and in combination, offer important efficiencies in organizing the large firms with multiple owners that have come to dominate developed market economies. We explore those efficiencies in detail elsewhere. ${ }^{3}$ What is important to note here is that while those characteristics and their associated efficiencies are now commonly taken for granted, prior to the beginning of the nineteenth century there existed only a handful of specially chartered companies that combined all five of these characteristics. The joint stock company with tradeable shares was not made generally available for business activities in England until 1844, and limited liability was not added to the form until $1855 .{ }^{4}$ While some American states developed the form for general use a few years earlier, all general business corporation statutes appear to date from well after 1800. By around 1900, however, every major commercial jurisdiction appears to have provided for at least one standard-form legal entity with the five characteristics listed above as the default rules, and this has remained the case ever since. Thus there was already strong and rapid convergence a century ago regarding the basic elements of the law of business corporations. It is, in general, only in the more detailed structure of corporate law that jurisdictions have varied significantly since then.

The five basic characteristics of the corporate form provide, by their nature, for a firm that is strongly responsive to shareholder interests. They do not, however, necessarily dictate how the interests of other participants in the firm-such as employees, creditors, other suppliers, customers, or society at large-will be accommodated. Nor do they dictate the way in which conflicts of interest among shareholders themselves-and particularly between controlling and noncontrolling shareholders-will be resolved. Throughout most of the twentieth century there has been debate over these issues and experimentation with alternative approaches to them.

\section{The Shareholder-Oriented (OR "STANDARD") Model}

- Recent years, however, have brought strong evidence of a growing consensus on these issues among the academic, business, and governmental elites in leading jurisdictions. The principal elements of this emerging consensus are that ultimate control over the corporation should rest with the shareholder class; the

2. See Henry Hansmann \& Reinier Kraakman, The Essential Role of Organizational Law, YALE L.J. (forthcoming 2000).

3. See Henry Hansmann, The Ownership of Enterprise (1996); Henry Hansmann \& Reinier Kraakman, What Is Corporate Law?, in The ANatomy of Corporate Law: A Comparative and FunCTIONAL APPROACH (Reinier Kraakman et al. eds., forthcoming 2001).

4. See Phlllip Blumberg, The Law of Corporate Groups: Substantive Law 9-20 (1988). 
managers of the corporation should be charged with the obligation to manage the corporation in the interests of its shareholders; other corporate constituencies, such as creditors, employees, suppliers, and customers, should have their interests protected by contractual and regulatory means rather than through participation in corporate governance; noncontrolling shareholders should receive strong protection from exploitation at the hands of controlling shareholders; and the market value of the publicly traded corporation's shares is the principal measure of its shareholders' interests. For simplicity, we shall refer to the view of the corporation comprised by these elements as the "standard shareholder-oriented model" of the corporate form (or, for brevity, simply "the standard model"). To the extent that corporate law bears on the implementation of this standard model - as to an important degree it does-this consensus on the appropriate conduct of corporate affairs is also a consensus as to the appropriate content of corporate law, and it is likely to have profound effects on the structure of that law.

\section{A. IN WHOSE INTEREST?}

As we argue in Part IV, there is today a broad normative consensus that shareholders alone are the parties to whom corporate managers should be accountable, resulting from widespread disenchantment with a privileged role for managers, employees, or the state in corporate affairs. This is not to say that there is agreement that corporations should be run in the interests of shareholders alone-much less that the law should sanction that result. All thoughtful people believe that corporate enterprise should be organized and operated to serve the interests of society as a whole, and that the interests of shareholders deserve no greater weight in this social calculus than do the interests of any other members of society. The point is simply that now, as a consequence of both logic and experience, there is convergence on a consensus that the best means to this end (that is, the pursuit of aggregate social welfare) is to make corporate managers strongly accountable to shareholder interests and, at least in direct terms, only to those interests. It follows that even the extreme proponents of the so-called "concession theory" of the corporation can embrace the primacy of shareholder interests in good conscience. ${ }^{5}$

5. In a hoary debate that cuts across jurisdictional boundaries, proponents of the view that corporations exist by virtue of a state "concession" or privilege have also been associated with the view that corporations ought to be governed in the interests of society-or all corporate constituencies-rather than in the private interest of shareholders alone. See, e.g., E. Merrick Dodd, Jr., For Whom Are Corporate Managers Trustees?, 45 Harv. L. Rev. 1145, 1148-50 (1932); Paul G. Mahoney, Contract or Concession? A Historical Perspective on Business Corporations (University of Virginia School of Law, Working Paper, 1999) (on file with author). Conversely, proponents of the view that the corporation is at bottom a contract among investors have tended to advance the primacy of shareholder interests in corporate governance.

In our view the traditional debate between concession and contract theorists is simply confused. On the one hand, corporations-whether "concessions" or contracts-should be regulated when it is in the 
Of course, asserting the primacy of shareholder interests in corporate law does not imply that the interests of corporate stakeholders must or should go unprotected. It merely indicates that the most efficacious legal mechanisms for protecting the interests of nonshareholder constituencies—or at least all constituencies other than creditors-lie outside of corporate law. For workers, this includes the law of labor contracting, pension law, health and safety law, and antidiscrimination law. For consumers, it includes product safety regulation, warranty law, tort law governing product liability, antitrust law, and mandatory disclosure of product contents and characteristics. For the public at large, it includes environmental law and the law of nuisance and mass torts.

Creditors, to be sure, are to some degree an exception. There remains general agreement that corporate law should directly regulate some aspects of the relationship between a business corporation and its creditors. Conspicuous examples include rules governing veil-piercing and limits on the distribution of dividends in the presence of inadequate capital. The reason for these rules, however, is that there are unique problems of creditor contracting that are integral to the corporate form, owing principally to the presence of limited liability as a structural characteristic of that form. These types of rules, however, are modest in scope. Outside of bankruptcy, they do not involve creditors in corporate governance, but rather are confined to limiting shareholders' ability to use the characteristics of the corporate form opportunistically to exploit creditors.

\section{B. WHICH SHAREHOLDERS?}

The shareholder-oriented model does more than assert the primacy of shareholder interests, however. It asserts the interests of all shareholders, including minority shareholders. More particularly, it is a central tenet in the standard model that minority or noncontrolling shareholders should receive strong protection from exploitation at the hands of controlling shareholders. In publicly traded firms, this means that all shareholders should be assured an essentially equal claim on corporate earnings and assets.

There are two conspicuous reasons for this approach, both of which are rooted in efficiency concerns. One reason is that, absent credible protection for noncontrolling shareholders, business corporations will have difficulty raising capital from the equity markets. The second reason is that the devices by which controlling shareholders divert to themselves a disproportionate share of corporate benefits commonly involve inefficient investment choices and management policies.

public interest to do so. On the other hand, the standard model is, in effect, an assertion that social welfare is best served by encouraging corporate managers to pursue shareholder interests. 


\section{THE IMPORT OF OWNERSHIP STRUCTURE}

It is sometimes said that the shareholder-oriented model of corporate law is well suited only to those jurisdictions in which one finds large numbers of firms with widely dispersed share ownership, such as the United States and the United Kingdom. A different model is appropriate, it is said, for those jurisdictions in which ownership is more concentrated, such as the nations of continental Europe. This view, however, is unconvincing.

Closely held corporations, like publicly held corporations, operate most efficiently when the law helps assure that managers are primarily responsive to shareholder interests and that controlling shareholders do not opportunistically exploit noncontrolling shareholders. The shareholder primacy model does not logically privilege any particular ownership structure. Indeed, both concentrated and dispersed shareholdings have been celebrated, at different times and by different commentators, for their ability to advance shareholder interests in the face of serious agency problems.

Equally important, every jurisdiction includes a range of corporate ownership structures. While both the U.S. and U.K. have many large firms with dispersed ownership, both countries also contain a far larger number of corporations that are closely held. Similarly, every major continental European jurisdiction has at least a handful of firms with dispersed ownership, and the number of such firms is evidently growing. It follows that every jurisdiction must have a system of corporate law that is adequate to handle the full range of ownership structures.

Thus, just as there was rapid crystallization of the core features of the corporate form in the late nineteenth century, at the beginning of the twenty-first century we are witnessing rapid convergence on the standard shareholderoriented model as a normative view of corporate structure and governance. We should also expect this normative convergence to produce substantial convergence in the practices of corporate governance and in corporate law.

\section{Forces of IDEOLOGICAL CONVERGENCE}

There are three principal factors driving consensus on the standard model: the failure of alternative models; the competitive pressures of global commerce; and the shift of interest group influence in favor of an emerging shareholder class. We consider these developments here in sequence.

\section{A. THE FAILURE OF ALTERNATIVE MODELS}

Debate and experimentation concerning the basic structure of corporate law during the twentieth century centered on the ways in which that law should accommodate the interests of nonshareholder constituencies. In this regard, three principal alternatives to a shareholder-oriented model were the traditional foci of attention. We term these the manager-oriented, labor-oriented, and state-oriented models of corporate law. Although each of these three alternative models has, at various points and in various jurisdictions, achieved some 
success both in practice and in received opinion, all three have ultimately lost much of their normative appeal.

\section{The Manager-Oriented Model}

In the United States, there existed an important strain of normative thought from the 1930s through the 1960s that extolled the virtues of granting substantial discretion to the managers of large business corporations. Merrick Dodd and John Kenneth Galbraith, for example, were conspicuously identified with this position, and Adolph Berle came to it late in life. ${ }^{6}$ At the core of this view was the belief that professional corporate managers could serve as disinterested technocratic fiduciaries who would guide business corporations to perform in ways that would serve the general public interest. The corporate social responsibility literature of the 1950 s can be seen as an embodiment of these views. ${ }^{7}$

The normative appeal of this view arguably provided part of the rationale for the various legal developments in U.S. law in the 1950s and 1960s that tended to reinforce the discretionary authority of corporate managers, such as the SEC proxy rules and the Williams Act. The collapse of the conglomerate movement in the 1970s and 1980s, however, largely destroyed the normative appeal of the managerialist model. It is now the conventional wisdom that, when managers are given great discretion over corporate investment policies, they tend to serve disproportionately their own interests, however well-intentioned managers may be. While managerial firms may be in some ways more efficiently responsive to nonshareholder interests than are firms that are more dedicated to serving their shareholders, the price paid in inefficiency of operations and excessive investment in low-value projects is now considered too great.

\section{The Labor-Oriented Model}

Large-scale enterprise clearly presents problems of labor contracting. Simple contracts and the basic doctrines of contract law are inadequate in themselves to govern the long-term relationships between workers and the firms that employ them-relationships that may be afflicted by, among other things, substantial transaction-specific investments and asymmetries of information.

6. Dodd and Berle conducted a classic debate on the subject in the $1930 \mathrm{~s}$, in which Dodd pressed the social responsibility of corporate managers while Berle championed shareholder interests. See Adolph A. Berle, Corporate Powers as Powers in Trust, 44 HaRv. L. Rev. 1049, 1049 (1931); Adolph A. Berle, For Whom Corporate Managers Are Trustees: A Note, 45 HARv. L. REv. 1365, 1367-68 (1932); Dodd, supra note 5, at 1145 . By the 1950 s, Berle seemed to have come around to Dodd's celebration of managerial discretion as a positive virtue that permits managers to act in the interests of society as a whole. See Adolph A. Berle, JR, Power Wrthout Property: A New Development in American Polmtical Economy 107-10 (1959) [hereinafter Berle, Power Without Property]. John Kenneth Galbraith takes a similar position in The New Industrial State. See John Kenneth Galbramt, The New INDUSTRIAL STATE (1967).

7. See, e.g., Berle, Power Without Property, supra note 6; Galbratth, supra note 6. For an important collection of essays arguing both sides of the question of managerial responsibility to the broader interests of society, see THE CoRPORATION IN MODERN SOCIETY (Edward Mason ed., 1959). 
Collective bargaining via organized unions has been one approach to those problems - an approach that lies outside corporate law, since it is not dependent on the organizational structure of the firms with which the employees bargain. Another approach, and one that importantly involves corporate law, has been to involve employees directly in corporate governance by, for example, providing for employee representation on the firm's board of directors. Although serious attention was given to employee participation in corporate governance in Germany as early as the Weimar Republic, unionism was the dominant approach everywhere until the Second World War. Then, after the War, serious experimentation with employee participation in corporate governance began in Europe. The results of this experimentation are most conspicuous in Germany, where, under legislation initially adopted for the coal and steel industries in 1951 and extended by stages to the rest of German industry between 1952 and 1976, employees are entitled to elect half of the members of the (upper-tier) board of directors in all large German firms. This German form of "codetermination" has been the most far-reaching experiment with employee participation. It is not unique, however. A number of other European countries have experimented in more modest ways, typically requiring between one and three labor representatives on the boards of large corporations. Moreover, the Dutch have adopted a wholly unique model for larger domestic companies that combines elements of the manager-, labor-, and state-oriented models. Under the Dutch "structure" regime, supervisory boards are self-appointing, although both labor and shareholders retain the right to object to the board appointments. In the event of an objection, the commercial court decides.

Enthusiasm for employee participation crested in the 1970s with the radical expansion of codetermination in Germany and the drafting of the European Community's proposed Fifth Directive on Company Law, ${ }^{8}$ under which Germanstyle codetermination would be extended throughout Europe. Employee participation also attracted considerable attention in the United States during that period, as adversarial unionism began to lose its appeal as a means of dealing with problems of labor contracting and, in fact, began to disappear from the industrial scene. Since then, worker participation in corporate governance has steadily lost power as a normative ideal. Despite repeated dilution, Europe's Fifth Directive has never become law, and it now seems highly unlikely that German-style codetermination will ever be adopted elsewhere.

The growing view today is that meaningful direct worker voting participation in corporate affairs tends to produce inefficient decisions, paralysis, or weak boards, and that these costs are likely to exceed any potential benefits that worker participation might bring. The problem, at root, seems to be one of governance. While direct employee participation in corporate decisionmaking

8. Amended Proposal for a Fifth Directive Founded on Article 54(3)(G) of the Treaty Concerning the Structure of Public Limited Companies and the Powers and Obligations of their Organs, 1983 O.J. (C 240) 2 . 
may mitigate some of the inefficiencies that can beset labor contracting, the workforce in typical firms is too heterogeneous in its interests to form an effective governing body - and the problems are magnified greatly when employees must share governance with investors, as in codetermined firms. In general, contractual devices, whatever their weaknesses, are (when supplemented by appropriate labor market regulation) evidently superior to voting and other collective choice mechanisms in resolving conflicts of interest among and between a corporation's investors and employees.'

Today, even inside Germany, few commentators argue for codetermination as a general model for corporate law in other jurisdictions. Rather, codetermination now tends to be defended in Germany as, at most, a workable adaptation to local interests and circumstances or, even more modestly, an experiment that, though of questionable value, would now be politically difficult to undo. ${ }^{10}$

\section{The State-Oriented Model}

Both before and after the Second World War, there was widespread support for a corporatist system in which the government would play a strong direct role in the affairs of large business firms to provide some assurance that private enterprise would serve the public interest. Technocratic government bureaucrats, the theory went, would help to avoid the deficiencies of the market through the direct exercise of influence in corporate affairs. This approach was most extensively realized in postwar France and Japan. In the United States, though there was little actual experimentation with this approach outside of the defense industries, the model attracted considerable intellectual attention. Perhaps the most influential exposition of the state-oriented model in the AngloAmerican world was Andrew Shonfield's 1968 book, Modern Capitalism, with its admiring description of French and Japanese style "indicative planning."11 The strong performance of the Japanese economy, and subsequently of other state-guided Asian economies, lent substantial credibility to this model even through the 1980s.

The principal instruments of state control over corporate affairs in corporatist economies generally lie outside of corporate law. They include, for example,

9. See Hansmann, supra note 3, at 89-119; Henry Hansmann, Probleme von Kollektiventscheidungen und Theorie der Firma-Folgerungen für die Arbeitnehmermitbestimmung, in OKONOMISCHE ANALYSE DES UNTERNEHMENSREChTs 287-305 (Claus Ott \& Hans-Bernd Schäfer eds., 1993); Henry Hansmann, Worker Participation and Corporate Governance, 43 U. Toronto L.J. 589, 589-606 (1993). On the weaknesses of German boards, see, for example, Mark Roe, German Securities Markets and German Codetermination, 1998 Colum. Bus. L. Rev. 167.

10. Some commentators, of course, continue to see codetermination as a core element of a unique Northern European form of corporate governance. See, e.g., Michel Albert, Capitalism vs. Capitalism (1993) (asserting generally the superiority of the "Rhine Model" of capitalism over the "Anglo-Saxon Model"). Even Albert concedes, however, the growing ideological power of shareholder-oriented corporate governance. See id. at 169-90.

11. Andrew Shonfield, Modern Capttalism: The Changing Balance of Public and Private Power 84-85 (1968). 
substantial discretion in the hands of government bureaucrats over the allocation of credit, foreign exchange, licenses, and exemptions from anticompetition rules. Nevertheless, corporate law also plays a role by, for example, weakening shareholder control over corporate managers (to reduce pressures on managers that might operate counter to the preferences of the state) and employing state-administered criminal sanctions rather than shareholder-controlled civil lawsuits as the principal sanction for managerial malfeasance (to give the state strong authority over managers that could be exercised at the government's discretion).

The state-oriented model, however, has now also lost most of its attraction. One reason is the move away from state socialism in general as a popular intellectual and political model. Important landmarks on this path include the rise of Thatcherism in England in the 1970s, Mitterand's abandonment of state ownership in France in the 1980s, and the sudden collapse of communism nearly everywhere in the 1990s. The relatively poor performance of the Japanese corporate sector after 1989, together with the more recent collapse of other Asian economies that were organized on state corporatist lines, has now discredited this model even further. Today, few would assert that giving the state a strong direct hand in corporate affairs has much normative appeal.

\section{Stakeholder Models}

Over the past decade, the literature on corporate governance and corporate law has sometimes advocated "stakeholder" models as a normatively attractive alternative to a strongly shareholder-oriented view of the corporation. The stakeholders involved may be employees, creditors, customers, merchants in a firm's local community, or even broader interest groups such as beneficiaries of a well-preserved environment. The stakeholders, it is argued, will be subject to opportunistic exploitation by the firm and its shareholders if corporate managers are accountable only to the firm's shareholders; corporate law must therefore ensure that managers are responsive to stakeholder interests as well.

While stakeholder models start with a common problem, they posit two different kinds of solutions. One group of stakeholder models looks to what we term a "fiduciary" model of the corporation, in which the board of directors functions as a neutral coordinator of the contributions and returns of all stakeholders in the firm. Under this model, only investors are given direct representation on the corporate board. Other stakeholders are protected by relaxing the board's duty or incentive to represent only the interests of shareholders, thus giving the board greater discretion to look after other stakeholders' interests.

The fiduciary model finds its most explicit recognition in U.S. law in the form of constituency statutes that permit boards to consider the interests of constituencies other than shareholders in mounting takeover defenses. Margaret Blair and Lynn Stout, sophisticated American advocates of the fiduciary model, also claim to find support for this normative model in other, broader aspects of 
U.S. corporate law. ${ }^{12}$ In the U.K., the fiduciary model is a key element in the ongoing debate over the duties of corporate directors. ${ }^{13}$

The second group of stakeholder models substitutes direct stakeholder representatives for fiduciary directors. In this "representative" model of the corporation, two or more stakeholder constituencies appoint representatives to the board of directors, which then elaborates policies that maximize the joint welfare of all stakeholders, subject to the bargaining leverage that each group brings to the boardroom table. The board functions ideally then as a kind of collective fiduciary, even though its individual members remain partisan representatives. The board of directors (or supervisory board) then becomes an unmediated "coalition of stakeholder groups" and functions as "an arena for cooperation with respect to the function of monitoring the management," as well as an arena for resolving "conflicts with respect to the specific interests of different stakeholder groups." 14

Neither the fiduciary nor the representative stakeholder models, however, constitute at bottom a new approach to the corporation. Rather, despite the new rhetoric with which the stakeholder models are presented, and the more explicit economic theorizing that sometimes accompanies them, they are at heart just variants on the older manager-oriented and labor-oriented models. Stakeholder models of the fiduciary type are in effect just reformulations of the manageroriented model, and they suffer the same weaknesses. While untethered managers may better serve the interests of some classes of stakeholders, such as a firm's existing employees and creditors, the managers' own interests will often come to have disproportionate prominence in their decisionmaking, with costs to some interest groups-such as shareholders, customers, and potential new employees and creditors-that outweigh any gains to the stakeholders who benefit. Moreover, the courts are evidently incapable of formulating and enforcing fiduciary duties of sufficient refinement to ensure that managers behave more efficiently and fairly.

Stakeholder models of the representative type closely resemble yesterday's labor-oriented model, though generalized to extend to other stakeholders as well, and are again subject to the same weaknesses. The mandatory inclusion of

12. See Margaret M. Blair \& Lynn A. Stout, A Team Production Theory of Corporate Law, 85 VA. L. REv. 247, 287-319 (1999).

13. See Company Law Reform Steering Group, Modern Company Law for a Competitive EnvironMENT: THE STRATEGIC FramEwORK 39-46 (1999) (setting forth the alternatives of maintaining the existing directorial duty of following enlightened shareholder interest or reformulating a "pluralist" duty to all major stakeholders in order to encourage firm-specific investment). After comment and discussion, however, the U.K. Company Law Reform Steering Group has chosen to propose the shareholder primacy norm, in accordance with the emerging consensus of legal scholars and practitioners everywhere. See Company Law Reform Steering Group, Modern Company Law for a Competitive ECONOMY: DeVEloping tHe Framework 29-31 (2000) (directors must act for the benefit of "members as a whole," that is, shareholders).

14. Reinhard H. Smith \& Gerald Spindler, Path Dependence, Corporate Governance and CompleMENTARITY-A COMment on BeBchuK ANd RoE 14, (Johann Wolfgang Goethe-Universitat Working Paper Series: Finance and Accounting No. 27, 1999). 
any set of stakeholder representatives on the board is likely to impair corporate decisionmaking processes with costly consequences that outweigh any gains to the groups that obtain representation. Thus, the same forces that have been discrediting the older models are also undermining the stakeholder model as a viable alternative to the shareholder-oriented model.

\section{B. COMPETITIVE PRESSURES TOWARD CONVERGENCE}

The shareholder-oriented model has emerged as the normative consensus not just because of the failure of the alternatives, but because important economic forces have made the virtues of that model increasingly salient. There are, broadly speaking, three ways in which a model of corporate governance can come to be recognized as superior: by force of logic, by force of example, and by force of competition. The emerging consensus in favor of the standard model has, in recent years, been driven with increasing intensity by each of these forces. We examine them here in turn.

\section{The Force of Logic}

An important source of the success of the standard model is that, in recent years, scholars and other commentators in law, economics, and business have developed persuasive reasons, which we have already explored above, to believe that this model offers greater efficiencies than the principal alternatives. One of these reasons is that, in most circumstances, the interests of equity investors in the firm-the firm's residual claimants-cannot adequately be protected by contract. Rather, to protect their interests, they must be given the right to control the firm. A second reason is that, if the control rights granted to the firm's equity-holders are exclusive and strong, they will have powerful incentives to maximize the value of the firm. A third reason is that the interests of participants in the firm other than shareholders can generally be given substantial protection by contract and regulation, so that maximization of the firm's value by its shareholders complements the interests of those other participants rather than competing with them. A fourth reason is that, even where contractual and regulatory devices offer only imperfect protection for nonshareholder interests, adapting the firm's governance structure to make it directly responsible to those interests creates more difficulties than it solves.

This reasoning is today reflected in much of the current literature on corporate finance and the economics of the firm-a literature that is becoming increasingly international. The consequence is to highlight the economic case for the shareholder-oriented model of governance. In addition, the persuasive power of the standard model has been amplified through its acceptance by a worldwide network of corporate intermediaries, including international law firms, the big five accounting firms, and the principal investment banks and consulting firms-a network whose rapidly expanding scale and scope give it exceptional influence in diffusing the standard model of shareholder-centered corporate governance. 


\section{The Force of Example}

The second source of the success of the standard model of corporate governance is the economic performance of jurisdictions in which it predominates. A simple comparison across countries adhering to different models-at least in very recent years-lends credence to the view that adherence to the standard model promotes better economic outcomes. The developed common-law jurisdictions have performed well in comparison to the principal East Asian and continental European countries, which are less in alignment with the standard model. The main examples include, of course, the strong performance of the American economy in comparison with the weaker economic performance of the German, Japanese, and French economies.

One might surely object that the success of the shareholder-oriented model is quite recent and will perhaps prove to be ephemeral, and that the apparent normative consensus based on that success will be ephemeral as well. After all, only fifteen years ago many thought that Japanese and German firms, which were clearly not organized on the shareholder-oriented model, were winning the competition, and that this was because they had adopted a superior form of corporate governance. ${ }^{15}$ However, this is probably a mistaken interpretation of the nature of the economic competition in recent decades, and it is surely at odds with today's prevailing opinion. The competition of the 1960s, '70s, and early ' 80 s was in fact among Japanese state-oriented corporations, German labor-oriented corporations, and American manager-oriented corporations. It was not until the late 1980s that one could speak of widespread international competition from shareholder-oriented firms.

\section{The Force of Competition}

The increasing internationalization of both product and financial markets has brought individual firms from jurisdictions adhering to different models into direct competition. It is now widely thought that firms organized and operated according to the shareholder-oriented model have had the upper hand in these more direct encounters as well. ${ }^{16}$ Such firms can be expected to have important competitive advantages over firms adhering more closely to other models. These advantages include access to equity capital at lower cost (including,

15. To be fair, however, American commentators tended to praise corporate governance in Germany and Japan in the name of the shareholder model. Thus, it was the purported ability of German banks to monitor managers and correctly value long-term business projects that caught the eye of American commentators after the $1970 \mathrm{~s}$, not codetermination or the labor-oriented model of the firm. See, e.g., Michael T. Jacobs, Short-Term America: The Causes and Cures of Our Business Myopia 69-71 (1991).

16. Indirect evidence to this effect comes from international surveys such as a recent poll of top managers conducted by The Financial Times to determine the world's most respected companies. Four of the top five most respected companies were American and hence operated under the shareholder model (the fifth was DaimlerChrysler, which is "almost" American for these purposes). Similarly, twenty-nine of the top forty firms were either American or British. See Annual Review, World's Most Respected Companies, FIN. TIMEs (LondON), Dec. 7, 1999. 
conspicuously, start-up capital), more aggressive development of new product markets, ${ }^{17}$ stronger incentives to reorganize along lines that are managerially coherent, and more rapid abandonment of inefficient investments.

These competitive advantages do not always imply that firms governed by the standard model will displace those governed by an alternative model in the course of firm-to-firm competition, for two reasons. First, firms operating under the standard model may be no more efficient than other firms in many respects. For example, state-oriented Japanese and Korean companies have demonstrated great efficiency in the management and expansion of standardized production processes, while German and Dutch firms such as Daimler Benz and Philips (operating under labor- and management-oriented models, respectively) have been widely recognized for engineering prowess and technical innovation. Second, even when firms governed by the standard model are clearly more efficient than their nonstandard competitors, the cost-conscious standard-model firms may be forced to abandon particular markets for precisely that reason. Less efficient firms organized under alternative models may overinvest in capacity or accept abnormally low returns on their investments in general, and thereby come to dominate a product market by underpricing their profitmaximizing competitors. But if the competitive advantages of standard-model firms do not necessarily force the displacement of nonstandard firms in established markets, these standard-model firms are likely, for the reasons offered above, to achieve a disproportionate share among start-up firms, in new product markets, and in industries that are in the process of rapid change. ${ }^{18}$

The ability of standard-model firms to expand rapidly in growth industries is magnified, moreover, by access to institutional investors and the international equity markets, which understandably prefer shareholder-oriented governance and are influential advocates of the standard model. Those equity investors, after all, are exclusively interested in maximizing the financial returns on their investments. Over time, then, the standard model is likely to win the competitive struggle on the margins, confining other governance models to older firms and mature product markets. As the pace of technological change continues to quicken, this competitive advantage should continue to increase.

\section{THE RISE OF THE SHAREHOLDER CLASS}

In tandem with the competitive forces just described, a final source of ideological convergence on the standard model is a fundamental realignment of

17. See, e.g., Roman Frydman et al., Why OWNership Matters? ENTRepreneurship and the Restructuring of ENTERPRISES IN CENTRAL Europe (1998) (asserting that firms privatized to outside owners proved superior to state firms and firms privatized to workers or previous managers in new market development).

18. In this regard it should be noted that small- and medium-sized firms in every jurisdiction are organized under legal regimes consistent with the standard model. Thus, shareholders-and shareholders alone-select the members of supervisory boards in the vast majority of (smaller) German and Dutch firms. These jurisdictions impose alternative labor- or manager-oriented regimes only on a minority of comparatively large firms. 
interest group structures in developed economies. At the center of this realignment is the emergence of a public shareholder class as a broad and powerful interest group in both corporate and political affairs across jurisdictions. There are two elements to this realignment. The first is the rapid expansion of the ownership of equity securities within broad segments of society, creating a coherent interest group that presents an increasingly strong countervailing force to the organized interests of managers, employees, and the state. The second is the shift in power, within this expanding shareholder class, in favor of the interests of minority and noncontrolling shareholders over those of inside or controlling shareholders.

\section{The Diffusion of Equity Ownership}

Stock ownership is becoming more pervasive everywhere. ${ }^{19}$ No longer is it confined to a small group of wealthy citizens. In the United States, this diffusion of share ownership has been underway since the beginning of the twentieth century. In recent years, however, it has accelerated substantially. Since the Second World War, an ever-increasing number of American workers have had their savings invested in corporate equities through pension funds. Over the same period, the mutual fund industry has also expanded rapidly, becoming the repository of an ever-increasing share of nonpension savings for the population at large. ${ }^{20}$ We have begun to see parallel developments in Europe and Japan, and to some extent elsewhere, as markets for equity securities have become more developed. ${ }^{21}$

The growing wealth of developed societies is a major factor underlying these changes. Even blue-collar workers now often have sufficient personal savings to justify investment in equity securities. No longer do labor and capital constitute clearly distinct interest groups in society. Workers, through share ownership, increasingly share the economic interests of other equity-holders. Indeed, in the United States, union pension funds are today quite active in pressing the view that companies must be managed in the best interests of their shareholders. ${ }^{22}$

19. Stock market capitalization as a percentage of GDP has risen dramatically in virtually every major jurisdiction over the past 20 years. In most European countries, the increase has been by a factor of three or four. See Schools Brief: Stocks in Trade, THE Economist, Nov. 13, 1999, at 85-86.

20. See generally The Global Corporate Governance Research Center, The Conference Board, Institutional Investment Report: Patterns of Institutional InVestment and Control in the United STATES (1997).

21. Latin America offers a telling example. In 1981, Chile became the first country in the region to set up a system of private pension funds. By 1995, Argentina, Colombia, and Peru had done the same. By 1996 , a total of $\$ 108$ billion was under management in Latin American pension funds, which by then had come to play an important role in the development of the local equity markets. In 1997, it was estimated that total assets would grow to $\$ 200$ billion by 2000 and to $\$ 600$ billion by 2011 . See A Private Affair, LATIN Fin., Dec. 1998, at 61; Stephen Fidler, Chile's Crusader for the Cause, Fin. Times (London), Mar. 14, 1997, at 3; Save Amigo Save, The Economist, Dec. 9, 1995, at 15.

22. See Stewart J. Schwab \& Randall S. Thomas, Realigning Corporate Governance: Shareholder Activism by Labor Unions, in EMPLOYEe RePRESENTATION IN THE EMERGING WORKPLACE: Alternatives/ Supplements to Collective Bargaining 341 (S. Estreicher ed., 1998). 


\section{The Shift in Balance Toward Public Shareholders}

As the example of the activist union pension funds suggests, diffusion of share ownership is only one aspect of the rise of the shareholder class. Another aspect is the new prominence of substantial institutions that have interests coincident with those of public shareholders and that are prepared to articulate and defend those interests. Institutional investors, such as pension funds and mutual funds-which are particularly prominent in the U.S. and are now rapidly growing elsewhere as well-are the most conspicuous examples of these institutions. Associations of minority investors in European countries provide another example. These institutions not only give effective voice to shareholder interests, but promote in particular the interests of dispersed public shareholders rather than those of controlling shareholders or corporate insiders. The result is that ownership of equity among the public at large, while broader than ever, is at the same time gaining more effective voice in corporate affairs.

Morever, the new activist shareholder-oriented institutions are today acting increasingly on an international scale. As a consequence, their influence now reaches well beyond their home jurisdictions. ${ }^{23}$ We now have not only a common ideology supporting shareholder-oriented corporate law, but also an organized interest group to press that ideology-an interest group that is broad, diverse, and increasingly international in its membership.

In the U.S., the principal effect of the expansion and empowerment of the shareholder class has been to shift interest group power from managers to shareholders. In Europe and Japan, the more important effect has been to shift power away from workers and the state and, increasingly, away from dominant shareholders. ${ }^{24}$

\section{WEAK FORCES FOR CONVERGENCE}

We have spoken here of a number of forces pressing toward international convergence on a relatively uniform standard model of corporate law. Those forces include the internal logic of efficiency, competition, interest group pressure, imitation, and the need for compatibility. We have largely ignored two other potential forces that might also press toward convergence: explicit efforts at cross-border harmonization, and competition among jurisdictions for corporate charters.

23. See, e.g., Greg Steinmetz \& Michael R. Sesit, Rising U.S. Investment in European Equities Galvanizes Old World, WALL ST. J., Aug. 4, 1999, at A1, A8 (describing U.S. investors as sparking important governance changes in large European companies).

24. Of particular interest are signs of change in the cross-ownership networks among major German and Japanese firms. New legislation proposed by the German government would eliminate the heavy (up to fifty percent) capital gains taxes on corporate sales of stock, which is expected to result in widespread dissolution of block holdings. See Haig Simonian, Germany to End Tax on Sale of Cross-Holdings, Fin. Times (London), Dec. 24, 1999, at 1. In Japan, keiretsu structures are beginning to unwind as a result of bank mergers and competitive pressure to seek higher returns on capital. See Paul Abrahams \& Gillian Tett, The Circle Is Broken, Fin. Times (London), Nov. 9, 1999, at 18. 


\section{Harmonization}

The European Union has been the locus of the most intense efforts to date at self-conscious harmonization of corporate law across jurisdictions. That process, however, has proved a relatively weak force for convergence: Where there exists substantial divergence in corporate law across member states, efforts at harmonization have generally borne little fruit. Moreover, harmonization proposals often have been characterized by an effort to impose throughout the E.U. regulatory measures of questionable efficiency, with the result that harmonization sometimes seems more an effort to avoid the standard model than to further it.

For these reasons, the other pressures toward convergence described above are likely to be much more important forces for convergence than are explicit efforts at harmonization. At most, we expect that, once the consensus for adoption of the standard model has become sufficiently strong, harmonization may serve as a convenient pretext for overriding the objections of entrenched national interest groups that resist reform of corporate law within individual states.

\section{Competition for Charters}

The American experience of competition among state jurisdictions suggests that cross-border competition for corporate charters can be a powerful force for convergence in corporate law and, in particular, for convergence on an efficient model..$^{25}$ It seems quite plausible, however, that the choice of law rules necessary for this form of competition will not be adopted in most jurisdictions until substantial convergence has already taken place. We expect that the most important steps toward convergence can and will be taken with relative rapidity before explicit cross-border competition for charters is permitted in most of the world, and that the latter process will ultimately be used, at most, as a means of working out the fine details of convergence and of ongoing minor experimentation and adjustment thereafter.

\section{Convergence of Governance Practices}

Thus far we have attempted to explain the sources of ideological convergence on the standard model of corporate governance. Our principal argument is on this normative level; we make the claim that no important competitors to the standard model of corporate governance remain persuasive today. This claim is consistent with significant differences among jurisdictions in corporate practice and law over the short run; ideological convergence does not necessarily mean rapid convergence in practice. There are many potential obstacles to rapid institutional convergence, even when there is general consensus on what constitutes best practice. Nevertheless, we believe that the developing ideological

25. See generally Roberta Romano, The Genius of American Corporate Law (1993). 
consensus on the standard model will have important implications for the convergence of practice and law over the long run.

We expect that the reform of corporate governance practices will generally precede the reform of corporate law, for the simple reason that governance practice is largely a matter of private ordering that does not require legislative action. Recent events in most developed jurisdictions-and in many developing ones-bear out this prediction. Under the influence of the ideological and interest group changes discussed above, corporate governance reform has already become the watchword not only in North America but also in Europe and Japan. Corporate actors are themselves implementing structural changes to bring their firms closer to the standard model. In the U.S., these changes include appointment of larger numbers of independent directors to boards of directors, reduction in overall board size, development of powerful board committees dominated by outsiders (such as audit committees, compensation committees, and nominating committees), closer links between management compensation and the value of the firm's equity securities, and strong communication between board members and institutional shareholders. In Europe and Japan, many of the same changes are taking place, though with a lag. Examples range from the OECD's promulgation of new principles of corporate governance, to recent decisions by Japanese companies to reduce board sizes and include nonexecutive directors (following the lead of Sony), to the rapid diffusion of stock option compensation plans for top managers in the U.K. and in the principal commercial jurisdictions of continental Europe.

\section{LEgAL CONVERGENCE}

Not surprisingly, convergence in the fine structure of corporate law proceeds more slowly than convergence in governance practices. Legal change requires legislative action. Nevertheless, we expect shareholder pressure (and the power of shareholder-oriented ideology) to force gradual legal changes, largely but not entirely in the direction of Anglo-American corporate and securities law. There are already important indications of evolutionary convergence in the realms of board structure, securities regulation, and accounting methodologies, and even in the regulation of takeovers.

\section{A. BOARD STRUCTURE}

With respect to board structure, convergence has been in the direction of a legal regime that strongly favors a single-tier board that is relatively small and that contains some insiders as well as a majority of outside directors. Mandatory two-tier board structures seem a thing of the past; the weaker and less responsive boards that they promote are justified principally as a complement to worker codetermination and thus share-indeed, constitute one of-the weaknesses of the latter institution. The declining fortunes of the two-tier board are reflected in the evolution of the European Union's Proposed Regulation on the 
Statute for a European Company. When originally drafted in 1970, that Regulation called for a mandatory two-tier board. In 1991, however, the Proposed Regulation was amended to permit member states to prescribe either a two-tier or a single-tier system. Meanwhile, on the practical side, France, which made provision for an optional two-tier board when the concept was more in vogue, has seen few of its corporations adopt the device. ${ }^{26}$

At the same time, jurisdictions that traditionally favored the opposite extreme of insider-dominated, single-tier boards have come to accept a significant complement of outside directors. In the U.S., the New York Stock Exchange listing rules have long mandated that independent directors serve on the important audit committees of listed firms $\mathrm{s}^{27}$ and, more recently, state law doctrine has created a strong role for outside directors in approving transactions where interests might be conflicted. ${ }^{28}$ In Japan, a similar evolution may be foreshadowed by the recent movement among Japanese companies, mentioned above, toward smaller boards and independent directors, and by the recent publication of a code of corporate governance principles advocating these reforms by a committee of leading Japanese managers. ${ }^{29}$ The result is convergence from both ends toward the middle: while two-tier boards themselves seem to be on the way out, countries with single-tier board structures are incorporating, in their regimes, one of the strengths of the typical two-tier board regime, namely the substantial role it gives to independent (outside) directors.

\section{B. DISCLOSURE AND CAPITAL MARKET REGULATION}

Regulation of routine disclosure to shareholders, intended to aid in policing corporate managers, is also converging conspicuously. Without seeking to examine this complex field in detail here, we note that major jurisdictions outside of the United States are reinforcing their disclosure systems, while the U.S. has been retreating from some of the more inexplicably burdensome of its federal regulations, such as the highly restrictive proxy solicitation rules that until recently crippled communication among American institutional investors. Indeed, the subject matter of mandatory disclosure for public companies is startlingly similar across the major commercial jurisdictions today. ${ }^{30}$

26. See Lauren J. Aste, Reforming French Corporate Governance: A Return to the Two Tier Board?, 32 Geo. WASH. J. INT'L L. \& ECoN. 1, 45 (1999).

27. See New York Stock Exchange, NYSE Listed Company Manual $\S 303.00$, available at http://www.nyse.com/listed/listed.html (last visited Nov. 1, 2000).

28. See, e.g., Weinberger v. UOP, Inc., 457 A.2d 701 (Del. 1983).

29. Corporate Governance Comm., Corporate Governance Forum of Japan, Corporate GoverNANCE PRINCIPLes 48-50 (1998).

30. This can be seen, for example, by comparing the E.U.'s Listing Particulars Directive with the SEC's Form S-1 for the registration of securities under the 1933 Act. If U.S. disclosure requirements remain more aggressive, one must remember that the E.U. Directives establish minimal requirements that member states can and do supplement. See John C. Coffee, Jr., The Future as History: The Prospects for Global Convergence in Corporate Governance and lis Implications, 93 Nw. U. L. REv. 641, 668-72 (1999). See generally Amir N. Licht, International Diversity in Securities Regulation: 
Similarly, uniform accounting standards are rapidly crystallizing out of the babble of national rules and practices into two well-defined sets of international standards: the GAAP accounting rules administered by the Financial Auditing Standards Board in the U.S. and the International Accounting Standards administered by the International Accounting Standards Committee in London. While important differences remain between the competing sets of international standards, these differences are far smaller than the variations among the national accounting methodologies that preceded GAAP and the new International Standards. The two international standards, moreover, are likely to converge further, if only because of the economic savings that would result from a single set of global accounting standards. ${ }^{31}$

\section{SHAREHOLDER SUITS}

Suits initiated by shareholders against directors and managers are now being accommodated in countries that had previously rendered them ineffective. Germany recently reduced the ownership threshold that qualifies shareholders to demand legal action (to be brought by the supervisory board or special company representative) against managing directors, dropping that threshold from a ten percent equity stake to the lesser of a five percent stake or a one million deutsche Mark stake when there is suspicion of dishonesty or illegality. ${ }^{32}$ Japan, in turn, has altered its rules on posting a bond to remove disincentives for litigation. At the same time, U.S. law is moving toward the center from the other direction by beginning to rein in the country's strong incentives for potentially opportunistic litigation. At the federal level, there are recently strengthened pleading requirements upon initiation of shareholder actions, new safe harbors for forward-looking company projections, and recent provision for lead shareholders to take control in class actions. State law rules, meanwhile, are making it easier for a corporation to get a shareholders' suit dismissed.

\section{TAKEOVERS}

Regulation of takeovers also seems headed for convergence. As it is, current differences in takeover regulation are more apparent than real. Hostile takeovers are rare outside the Anglo-American jurisdictions, principally owing to the more concentrated patterns of shareholdings outside those jurisdictions. As sharehold-

\footnotetext{
Roadblocks on the Way to Convergence, 20 CARDOZO L. REv. 227 (1998) (discussing convergence in disclosure rules, accounting standards, and corporate governance). In addition, a recent survey of the practices of European issuers finds that actual disclosure practices track U.S. and U.K. disclosure standards even more closely than legal disclosure requirements do. See HowELL JACKSON \& ERIC PAN, Regulatory Competttion in International Securtties Markets: Evidence from Europe in 1999 34-39 (John M. Olin Center for Law, Econ. \& Bus. Working Paper, Sept. 18, 2000).

31. See, e.g., Elizabeth MacDonald, U.S. Accounting Board Faults Global Rules, WALL ST. J., Oct. 18,1999 , at A1.

32. See Theodor Baums, Corporate Governance in Germany: System and Current Developments pt. VIII.1 (Universitat Osnabruck Working Paper, 1999).
} 
ing patterns become more homogeneous (as we expect they will), and as corporate culture everywhere becomes more accommodating of takeovers (as it seems destined to), takeovers presumably will become much more common in Europe, Japan, and elsewhere. ${ }^{33}$

Moreover, where operative legal constraints on takeovers in fact differ, they show signs of convergence. In particular, for several decades the U.S. has been increasing its regulation of takeovers, placing additional constraints both on the ability of acquirers to act opportunistically and on the ability of incumbent managers to entrench themselves or engage in self-dealing. With the widespread diffusion of the "poison pill" defense, and the accompanying limits that courts have placed on the use of that defense, partial hostile tender offers of a coercive character are a thing of the past-a result similar to that which European jurisdictions have accomplished with a "mandatory bid rule," requiring acquirers of control to purchase all shares in their target companies at a single price.

To be sure, jurisdictions diverge in other aspects of takeover law where the points of convergence are still uncertain. For example, American directors enjoy far more latitude to defend against hostile takeovers than do directors in most European jurisdictions. Under current Delaware law, incumbent boards have authority to resist hostile offers, although they remain vulnerable to bids that are tied to proxy fights at shareholder meetings. As the incidence of hostile takeovers increases in Europe, European jurisdictions may incline toward Delaware by permitting additional defensive tactics. Alternatively, given the dangers of managerial entrenchment, Delaware may move toward European norms by limiting defensive tactics more severely. While we cannot predict where the equilibrium point will lie, it is a reasonable conjecture that the law on both sides of the Atlantic will ultimately converge on a single regime.

\section{E. JUDICIAL DISCRETION}

There remains one very general aspect of corporate law on which one might feel that convergence will be slow to come: the degree of judicial discretion in ex post resolution of disputes among corporate actors. Such discretion has long been much more conspicuous in the common-law jurisdictions, and particularly in the U.S., than in the civil-law jurisdictions. Even here, though, there is good reason to believe that there will be strong convergence across systems over time. Civil-law jurisdictions, whether in the form of court decisionmaking or

33. Already Europe has seen a remarkable wave of takeovers in 1999, culminating in the largest hostile takeover in history: Vodaphone's acquisition of Mannesmann. In addition, many established jurisdictions are adopting rules to regulate tender offers that bear a family resemblance to the Williams Act or to the rules of the London City Code. See, for example, Brazil's tender offer regulations, Secs. Comm'n Ruling 69, Sept. 8. 1987, Arts. 1-4, and Italy's recently adopted reform of takeover regulation, Legislative Decree 58 of February 24, 1998 (the Financial Markets Act or so-called "Draghi Reform"), cited in Studio Legale Abbatesciann: Associazione Professionale di Avvocati e Dottori CommercialISTI, The New Italian Law on Takeovers, at http://www.sla.it/takeovers.htm (last visited Nov. 1, 2000). 
arbitration, seem to be moving toward a more discretionary model. ${ }^{34}$ United States securities law is civilian in spirit and elaborated by detailed rules promulgated by the Securities Exchange Commission (SEC). At the same time, there are signs of growing discomfort with the more extreme forms of unpredictable ex post decisionmaking that have sometimes been characteristic of, say, the Delaware courts. Scholars have begun to suspect the open-ended texture of Delware case law, ${ }^{35}$ while the American Law Institute has offered a code-like systemization of corporate law in the form of the Corporate Governance Project, which includes even the notoriously vague and open-ended U.S. case law that articulates the fiduciary duties of loyalty and care.

\section{Potential Obstacles to Convergence}

To be sure, important interests are threatened by movement toward the standard model, and those interests can be expected to serve as a brake on change. We doubt, however, that such interests will be able to stave off for long the reforms called for by the growing ideological consensus focused on the standard model.

To take one example, consider the argument, prominently made by Lucian Bebchuk and Mark Roe, ${ }^{36}$ that the private value extracted by corporate controllers (controlling shareholders or powerful managers) will long serve as a barrier to the evolution of efficient ownership structures, governance practices, and corporate law. The essential structure of the Bebchuk and Roe argument is as follows: In jurisdictions lacking strong protection for minority shareholders, controlling shareholders divert to themselves a disproportionate share of corporate cash flows. The controlling shareholders thus have an incentive to avoid any change in their firm's ownership or governance, or in the regulation to which their firm is subject, that would force them to share the corporation's earnings more equitably. Moreover, these corporate insiders have the power in many jurisdictions to prevent such changes. Their position as controlling shareholders permits them to block changes in the firm's ownership structure merely by refusing to sell their shares. Their position also permits them to block changes in governance by selecting the firm's directors. And, in those societies in which-as in most of Europe-closely controlled firms dominate the economy, the wealth and collective political weight of controlling shareholders permits

34. See The Holzmüller decision of the German Federal Court, BGHZ, Zivilsenat, II ZR 174/80 (1982) (German case law extension of shareholder right to vote to all fundamental corporate transactions).

35. See, e.g., Douglas M. Branson, The Chancellor's Foot in Delaware: Schnell and Its Progeny, 14 J. CoRP. L. 515 (1989); Ehud Kamar, A Regulatory Competition Theory of Indeterminancy in Corporate Law, 98 Colum. L. Rev. 1908 (1998); Jonathan R. Macey \& Geoffrey P. Miller, Toward an InterestGroup Theory of Delaware Corporate Law, 65 Tex. L. Rev. 469 (1987).

36. See Lucian Bebchuk \& Mark Roe, A Theory of Path Dependence in Corporate Ownership and Governance, 52 STAN. L. REv. 127 (1999). 
them to block legal reforms that would compromise their disproportionate private returns.

This pessimistic view seems unwarranted, though. If, as the developing consensus view holds, the standard shareholder-oriented governance model maximizes corporate value, controlling shareholders who are motivated chiefly by economic considerations may not wish to retain control of their firms. And, even if nonmonetary considerations lead insiders to retain control, the economic significance of firms dominated by these insiders is likely to diminish over time both in their own jurisdictions and in the world market.

\section{A. TRANSACTIONS TO CAPTURE SURPLUS}

First, consider the case of controlling shareholders ("controllers") who wish to maximize their financial returns. Suppose that the prevailing legal regime permits controlling shareholders to extract large private benefits from which public shareholders are excluded. Predictably, these controllers will sell their shares only if they receive a premium price that captures the value of their private benefits, and they will reject any corporate governance reform that reduces the value of those returns. That such controllers will prefer to increase their own returns over increasing returns to the corporation does not imply, however, that they will reject governance institutions or ownership structures that maximize firm value. Bebchuk and Roe are too quick to conclude that controllers cannot themselves profit by facilitating efficient governance.

Controllers who extract large private benefits from public companies are likely to indulge in two forms of inefficient management. First, they may select investment projects that maximize their own private returns over returns to the firm. For example, a controller might select a less profitable investment project over a more profitable one precisely because it offers opportunities for lucrative self-dealing. Second, controllers are likely to have a preference for retaining and reinvesting earnings over distributing them, even when it is inefficient to do so. The reason is that formal corporate distributions must be shared with minority shareholders, while earnings reinvested in the firm remain available for subsequent conversion into private benefits-for example, through self-dealing transactions. Moreover, a controller's incentive to engage in both forms of inefficient behavior increases markedly if-as has been common in Europe-she employs devices such as stock pyramids, corporate cross-holdings, and dual-class stock to maintain a lock on voting control while reducing her proportionate equity stake. ${ }^{37}$

Where law enforcement is effective, however, inefficient behavior itself creates strong financial incentives to pursue more efficient ownership and governance structures. When share prices are sufficiently depressed, anyone-

37. See Luclan Bebchuk et al., Stock Pyramids, Cross-Ownership, and Dual Class Equity: The Creation and Agency Costs of Separating Control from Cash Flow Rights (NBER Working Paper No. 6951, 1999). 
including controllers themselves-can generate net gains by introducing more efficient governance structures. It follows that controllers who can capture most or all of the value of these efficiency gains stand to profit privately even more than they profit by extracting non-pro-rata benefits from poorly governed firms. Controllers can capture these efficiency gains, moreover, in at least two ways: (1) by selling out at a premium price reflecting potential efficiency gains to a buyer or group of buyers that is willing and able to operate under nonexploitative governance rules; or (2) by buying up minority shares (at depressed prices) and either managing their firms as sole owners or reselling their entire firms to buyers with efficient ownership structures.

For controllers to extract these efficiency gains, however, efficient restructuring must be legally possible: That is, the legal regime must offer means by which restructured firms can commit to good governance practices. This can be done in several ways without threatening the private returns of controllers who have not yet undertaken to restructure. One solution is an optional corporate and securities law regime that is more dedicated to protecting minority shareholders than the prevailing regime. For example, firms can be permitted to list their shares on foreign exchanges with more rigorous shareholder-protection rules. Another solution is simply to enforce shareholder-protective provisions that are written into a restructured firm's articles of incorporation.

It follows that even financially self-interested controllers have an incentive to promote the creation of legal regimes in which firms at least have a choice of forming along efficient lines, which, as we have argued, today means along shareholder-oriented lines. Once such an (optional) efficient regime has been established and many of the existing exploitative firms have taken advantage of the regime to profit from an efficient restructuring, there should be a serious reduction in the size of the interest group that wishes even to maintain as an option the old regime's accommodation of firms that are exploitative toward noncontrolling shareholders.

Bebchuk and Roe appear to assume that such developments will not occur because the law will inhibit controlling shareholders from seeking efficient restructuring by forcing them to share any gains from the restructuring equitably with noncontrolling shareholders. It is more plausible, however, to suppose that the law will allow controlling shareholders to claim the gains associated with an efficient restructuring - by means of techniques such as freezeout mergers and coercive tender offers-in jurisdictions where controllers are able to extract large private benefits from ordinary corporate operations. In short, if current controlling shareholders are interested just in maximizing their financial returns, we can expect substantial pressure toward the adoption of efficient law.

\section{B. CONTROLLERS WHO WISH TO BUILD EMPIRES}

Controlling shareholders do not always, however, wish to maximize their financial returns. Rather-and we suspect this is often true in Europe-they may also seek nonpecuniary returns. For example, a controlling shareholder 
may wish simply to be on top of the largest corporate empire possible, and therefore be prepared to overinvest in building market share by selling at a price too low to maximize returns while reinvesting all available returns in expanded capacity and research and development. Alternatively, a controller may be willing to accept a low financial return in order to indulge a taste for a wide range of other costly practices, from putting incompetent family members in positions of responsibility to preserving quasi-feudal relations with employees and their local communities. Such practices may even be efficient if the controller values his nonpecuniary returns more than he would the monetary returns that are given up. Where the controller shares ownership with noncontrolling shareholders who do not value the nonpecuniary returns, though, there is the risk that the controlling shareholder will exploit the noncontrolling shareholders by refusing to distribute the firm's earnings and instead reinvesting those earnings in low-return projects that are valued principally by the controller. ${ }^{38}$

Efficiency-enhancing control transactions of the type described in the preceding section may have little to offer controlling shareholders of this type, since the restructuring may require that they give up control of the firm, and hence give up not only the nonpecuniary returns they were purchasing for themselves with the noncontrolling shareholders' money, but also the nonpecuniary returns they were purchasing with their own share of the firm's invested capital. Thus, controlling shareholders who value nonpecuniary gains will have less incentive than controllers whose motives are purely financial to favor efficient corporate legal structures.

Moreover, inefficient firms with such controllers may survive quite nicely in competitive markets and, in fact, expand, despite their inefficiencies. For example, if the controllers place value only on the size of the firm they control, they will continue to reinvest in expansion so long as the return offered simply exceeds zero, with the result that they can and will take market share from competing firms that are managed much more efficiently but must pay their shareholders a market rate of return.

Jurisdictions with large numbers of firms dominated by controllers with nonpecuniary motivations will, therefore, feel relatively less pressure than other jurisdictions to adopt standard-model corporate law. Yet even in those jurisdictions-which may include much of Western Europe today-the pressure for moving toward the standard model is likely to grow irresistibly strong in the relatively near future. We briefly explore here several reasons for this.

38. This can, of course, happen only where the controllers somehow have been able to mislead the noncontrolling shareholders. If the latter shareholders purchased their shares knowing that they would not have control, and that the controllers would divert a share of returns to themselves through inefficient investments, then they presumably paid a price for the shares that was discounted to reflect this diversion, leaving the noncontrolling shareholders with a market rate of return on their investment. 


\section{The Insiders' Political Clout Will Be Insufficient to Protect Them}

To begin with, the low profitability of firms that pursue nonpecuniary returns is likely to select against their owners as controllers of industry. As long as the owners of these firms subsidize low-productivity practices, they become progressively poorer relative to investors in new businesses and owners of established firms who seek either to enhance shareholder value or to sell out to others who will, with the result that economic and political influence will shift to the latter.

Furthermore, the success of firms following shareholder-oriented governance practices is likely to undermine political support for alternative models of corporate governance for two reasons. First, as we have suggested above, the rise of a shareholder class with growing wealth creates an interest group to press for reform of corporate governance to encourage value-enhancing practices and restrain controlling shareholders from extracting private benefits. Companies, whether domestic or foreign, that attract public shareholders and pension funds by promising a better bottom line also create natural enthusiasts for law reform and the standard model.

The second reason for a decline in the appeal of alternative styles of corporate governance is the broader phenomenon of ideological convergence on the standard model. Where previous ideologies may have celebrated the noblesse oblige of quasi-feudal family firms or the industrial prowess of huge conglomerates ruled by insiders, the increasing salience of the standard model makes empire-building and domination suspect, and the extraction of private value at the expense of minority shareholders illegitimate. Costly governance practices therefore become increasingly hard to sustain politically. Viewed through the lens of the new ideology, the old practices are not only inefficient but also unjust, since they deprive ordinary citizens, including pensioners and small investors, of a fair return on their investments. As civil society grows more democratic, the privileged returns of controlling shareholders, leading families, and entrenched managers become increasingly suspect.

Indeed, we expect that the social values that make it so prestigious for families to control corporate empires in many countries will change importantly in the years to come. The essentially feudal norms we now see in many patterns of industrial ownership will be displaced by social values that place greater weight on social egalitarianism and individual entrepreneurship, with the result that there will be an ever-dwindling group of firms dominated by controllers who place great weight on the nonpecuniary returns from presiding personally over a corporate fiefdom.

\section{The Insiders Who Preserve Their Firms and Legal Protections Will Become Increasingly Irrelevant}

Finally, even if dominant corporate controllers successfully block reform for some period of time in any given jurisdiction, they are likely to become increasingly irrelevant in the domestic economy, the world economy, or both. At home, as we have already noted, the terms on which public equity capital 
becomes available to finance new firms and new product markets are likely to be dominated by the standard model. Venture capital investments and initial public offerings are unlikely to occur if minority investors are not offered significant protection. This protection can be provided without disturbing the older, established firms by establishing separate standard-model institutions that apply only to new firms. An example of this is the Neuer Markt in the Frankfurt Stock Exchange, which provides the additional protection of enhanced disclosure and GAAP accounting standards for investors in start-up companies in search of equity capital, while leaving the less rigorous older rules in place for already established firms.

Moreover, to the extent that domestic law or domestic firms fail to provide adequate protections for public shareholders, other jurisdictions can supply the protection of the standard model. Investment capital can flow to other countries and to foreign firms that do business in the home jurisdiction. Alternatively, domestic companies may be able to reincorporate in foreign jurisdictions or bind themselves to comply with the shareholder protections offered by foreign law by listing on a foreign exchange (as some Israeli firms now do by listing on NASDAQ). ${ }^{39}$

Through devices such as these that effectively permit new firms to adopt a model that differs from that applicable to old firms, the national law and governance practices that protect controlling insiders in established firms can be maintained without crippling the national economy. The result is to partition off, and grandfather in, the older family-controlled or manager-dominated firms, whose costly governance practices will make them increasingly irrelevant to economic activity even within their local jurisdictions.

\section{EFFiCient Non-CONVERGENCE}

Not all divergence among corporate law regimes reflects inefficiency. Efficient divergence can arise either through adaptation to local social structures or through fortuity. Neither logic nor competition is likely to create strong pressure for this form of divergence to disappear. Consequently, it could survive for a considerable period of time. Still, though the rate of change may be slower, there is good reason to believe that even the extent of efficient divergence, like the extent of inefficient divergence, will continue to decrease relatively quickly.

\section{A. DIFFERENCES IN INSTITUTIONAL CONTEXT}

Sometimes jurisdictions choose alternative forms of corporate law because those alternatives complement other national differences in, for example, forms of shareholdings, means for enforcing the law, or related bodies of law such as bankruptcy. A case in point is the new Russian corporation statute, which

39. See, e.g., Coffee, supra note 30, at 674-76; Edward Rock, Mandatory Disclosure as Credible Commitment: Going Public, Opting in, Opting Out, and Globalzzation (University of Pennsylvania Institute for Law and Economics Working Paper, 1998). 
deviates self-consciously from the type of statute that the standard model would call for in more developed economies. To take just one example, the Russian statute imposes cumulative voting on all corporations as a mandatory rule, in strong contrast to the corporate law of most developed countries. The reason for this approach was largely to ensure some degree of shareholder influence and access to information in the context of the peculiar pattern of shareholdings that has become commonplace in Russia as a result of that country's unique process of mass privatization. ${ }^{40}$

Nevertheless, the efficient degree of divergence in corporate law appears much smaller than the divergence in the other institutions in which corporate activity is embedded. For example, efficient divergence in creditor protection devices is probably much narrower than observed differences in the sources and structure of corporate credit. Similarly, the efficient array of mechanisms for protecting shareholders from managerial opportunism appears much narrower than the observed variety across jurisdictions in patterns of shareholdings.

Moreover, the economic institutions and legal structures in which corporate law must operate are themselves becoming more uniform across jurisdictions. This is conspicuously true, for example, of patterns of shareholdings. All countries are beginning to face, or need to face, the same varied types of shareholders, from controlling blockholders to mutual funds to highly dispersed individual shareholders. Some of this is driven by the converging forces of internal economic development. Thus, privatization of enterprise, increases in personal wealth, and the need for start-up finance (which is aided by a public market that offers an exit for the initial private investors) all promote an increasing incidence of small shareholdings and a consequent need for strong protection for minority shareholders. The globalization of capital markets presses to the same end. Hence Russia, to return to our earlier example, will presumably evolve over time toward the patterns of shareholdings typical of developed economies, and it will ultimately feel the need to conform its shareholder voting rules more closely to the rules found in those economies.

\section{B. HARMLESS MUTATIONS}

In various cases we anticipate that there will be little or no efficiency difference among multiple alternative corporate law rules. In these cases, the pressures for convergence are lessened, although not entirely eliminated (since we still expect global investors to exert pressure to standardize).$^{41}$ Accounting

40. Following Russian voucher privatization in 1993, managers and other employees typically held a majority of shares in large companies. Publicly held shares were mostly widely dispersed, but there was often at least one substantial outside shareholder with sufficient holdings to exploit a cumulative voting rule to obtain board representation. See Bernard Black \& Reinier Kraakman, A Self-Enforcing Model of Corporate Law, 109 HaRv. L. REv. 1911, 1922-23 (1996).

41. Ronald Gilson refers to processes in which facially different governance structures or legal rules develop to solve the same underlying functional problem as "functional convergence." RonALD J. Gilson, Globalizing Corporate Governance: Convergence of Form or Function (Columbia Law 
standards offer an example. As we noted earlier, there are currently two different accounting methodologies that have achieved prominence among developed nations: the American GAAP and the European-inspired International Accounting Standards. Because these two sets of standards evolved separately, they differ in many significant details. From the best current evidence, however, neither obviously dominates the other in terms of efficiency.

If the economies involved were entirely autarchic, both accounting standards might well survive indefinitely with no sacrifice in efficiency. The increasing globalization of the capital markets, however, imposes strong pressure on all countries not only to adopt one or the other of these regimes but also to select a single common accounting regime. Over time, then, the network efficiencies of a common standard form in global markets are likely to eliminate even this and other forms of fortuitous divergence in corporate law.

\section{INEFFICIENT CONVERGENCE}

Having just recognized that efficiency does not always dictate convergence in corporate law, we must also recognize that the reverse can be true as well: A high degree of convergence need not always reflect efficiency. The most likely sources of such inefficient convergence are flaws in markets or in political institutions that are widely shared by modern economies and that are reinforced rather than mitigated by cross-border competition.

\section{A. THIRD-PARTY COSTS: CORPORATE TORTS}

Perhaps the most conspicuous example of inefficient convergence is the rule-already universal, with only minor variations from one jurisdiction to the next - that limits shareholder liability for corporate torts. This rule induces inefficient risk-taking and excessive levels of risky activities-inefficiencies that appear to outweigh by far any offsetting benefits, such as reduced costs of litigation or the smoother functioning of the securities markets. As we have argued elsewhere, a general rule of unlimited pro rata shareholder liability for corporate torts appears to offer far greater overall efficiencies. ${ }^{42}$

Why, then, has there been universal convergence on an inefficient rule? The obvious answer is that neither markets nor politics works well to represent the

School, Center for Law and Economics Working Paper No. 174, 2000). On the assumption that formal law and governance practices are embedded in larger institutional contexts that change only slowly, Gilson conjectures that functional convergence is likely to outpace formal convergence. Such functional convergence, when it occurs, is what we term harmless mutation. In contrast to Gilson, however, we believe that formal law and governance structures are less contextual and more malleable than is often assumed, once the norm of shareholder primacy is accepted. Functional convergence-rather than straightforward imitation-is thus less necessary than Gilson supposes. We also suspect that close substitutes among alternative governance structures and legal rules are less widespread than Gilson implies.

42. See Henry Hansmann \& Reinier Kraakman, Toward Unilimited Shareholder Liability for Corporate Torts, 100 YALE L.J. 1879, 1882-83 (1991). 
interests of the persons who bear the direct costs of the rule, namely tort victims. Since, by definition, torts involve injuries to third parties, the parties affected by the rule-corporations and their potential tort victims-cannot contract around the rule to capture and share the gains from its alteration. At the same time, owing to the highly stochastic nature of most corporate torts, tort victims-and particularly the very large class of potential tort victims-do not constitute an easily organized political interest group. ${ }^{43}$ Moreover, even if a given jurisdiction were to adopt a rule of shareholder liability for corporate torts, difficulties in enforcement would arise from the ease with which shareholdings or incorporation can today be shifted to other jurisdictions that retain the rule of limited liability.

\section{B. MANAGERIALISM}

A second example of inefficient convergence, arguably, is the considerable freedom enjoyed by managers in almost all jurisdictions to protect their prerogatives in cases when they might conflict with those of shareholders, particularly including managers' ability to defend their positions against hostile takeover attempts. Again, political and market failures seem responsible. Dispersed public shareholders, who are the persons most likely to be disadvantaged by the power of entrenched managers, face potentially serious problems of collective action in making their voice felt. Managers, whose positions make them a powerful and influential interest group everywhere, can use their political influence to keep the costs of collective action high-for example, by making it hard for a hostile acquirer to purchase an effective control block of shares from current shareholders. Corporate law might therefore converge, not precisely to the shareholder-oriented standard model that represents the ideological consensus, but rather to a variant of that model that has a slight managerialist tilt.

\section{HOW BIG A PROBLEM?}

The problem of inefficient convergence in corporate law appears to be a relatively limited one, however. Tort victims aside, the relations among virtually all actors directly affected by the corporation are heavily contractual, which tends to give those actors a common interest in establishing efficient law. Moreover, as our earlier discussion has emphasized, shareholders, managers, workers, and voluntary creditors either have acquired or are acquiring a powerful interest in efficient corporate law. Indeed, limited liability in tort arguably should not be considered a rule of corporate law at all, but instead should be viewed as a rule of tort law. And even limited liability in tort may come to be abandoned as large-scale tort damage becomes more common and, consequently, of greater political concern. We already see some movement in this

43. By way of contrast, the largely nonstochastic tort of environmental pollution has made an easier focus for political organizing in the United States and, as noted in the text below, has led to strong legislation that partially pierces the corporate veil for firms that pollute. 
direction in U.S. environmental law, which pushes aside the corporate veil to a startling degree in particular circumstances.

\section{CONCLUSION}

The triumph of the shareholder-oriented model of the corporation over its principal competitors is now assured, even if it was problematic as recently as twenty-five years ago. Logic alone did not establish the superiority of this standard model or of the prescriptive rules that it implies, which establish a strong corporate management with duties to serve the interests of shareholders alone, as well as strong minority shareholder protections. Rather, the standard model earned its position as the dominant model of the large corporation the hard way, by out-competing during the post-World War II period the three alternative models of corporate governance: the managerialist model, the labororiented model, and the state-oriented model.

If the failure of the principal alternatives has established the ideological hegemony of the standard model, though, perhaps this should not come as a complete surprise. The standard model has never been questioned for the vast majority of corporations. It dominates the law and governance of closely held corporations in every jurisdiction. Most German companies do not participate in the codetermination regime, and most Dutch companies are not regulated by the managerialist "structure" regime. Similarly, the standard model of shareholder primacy has always been the dominant legal model in the two jurisdictions where the choice of models might be expected to matter most: the U.S. and the U.K. The choice of models matters in these jurisdictions because large companies often have highly fragmented ownership structures. In continental Europe, where most large companies are controlled by large shareholders, ${ }^{44}$ the interests of controlling shareholders traditionally dominate corporate policy no matter what the prevailing ideology of the corporate form.

We predict, therefore, that as equity markets evolve in Europe and throughout the developed world, the ideological and competitive attractions of the standard model will become indisputable, even among legal academics. And as the goal of shareholder primacy becomes second nature even to politicians, convergence in most aspects of the law and practice of corporate governance is sure to follow.

44. See Rafael La Porta et al., Corporate Ownership Around the World, 54 J. FIN. 471, 505 (1999) (stating that large firms tend to have controlling shareholders in all but common-law jurisdictions). 